\title{
The Academic Achievement of Students at Colleges of Higher Education in Relation to Admission Requirements
}

\author{
J.M. LABANI \\ Civil Engineering Department, Faculty of Engineering, \\ King Abdulaziz University, Jeddah, Saudi Arabia
}

\begin{abstract}
The investigation attempts to define the relationship between college admission requirements and the academic achievement of students. The academic records of 600 students were taken at random from twelve colleges and analyzed statistically. The investigation revealed an almost complete lack of correlation, at 5\% level of significance, between admission requirements and academic achievement.

Recommendations are made to alter present admission requirements and procedures, changes to the educational environment at the last phases of general education, and unification of the educational authorities
\end{abstract}

\section{Introduction}

Admission requirements at universities are the basis of selection procedures by which applications for admissions are accepted or rejected. The conditions are based upon past academic performance as suggested by the grades of the General Certificate of Education, GCE. The minimum requirements for admission differ from one college to another. Among the influences on admission policies are :

1. The availability of sufficient space and facilities.

2. The availability of enough experienced staff.

3. Applicants' marks in the General Certificate of Education.

4. Projected market manpower requirement, in number and quality, for graduates of specific colleges.

5. Non-educational pressures: Financial, social, etc. 
Thus, the scope of a coherent admission policy extends beyond publicly enunciated admission requirements and procedure. Yet, it is these conditions and procedures which concern the student, the parent, and the population at large, and form their attitudes towards institutions of higher education. It is also the formulation of these conditions and their implementation which appear to take up a significant amount of the time and energy of the administrators and academic staff. Accordingly, investigations of admission requirements are necessary. The present investigation was carried out on the academic records of 600 students from twelve colleges. Its objective is to attempt to define the relationship between academic achievement of students in two different environments, namely, that of genral and university education. In other words, the investigation attempts to answer the following question: Can expectations be properly based on extrapolation of records of past performance in the dynamic state of development?

\section{Basic Data}

The academic records of 50 students were taken at random from the student population of each of twelve colleges and investigated. These records consisted of the results of the General Certificate of Education, GCE, and the Grade Point Average, GPA, obtained at the university. The GPA of a student is the total number of points gained divided by the number of credit hours attempted. It may, therefore, be considered a measure of the efficiency of the student in the pursuit of his objective. Conversely, it may be a measure of the academic institution's efficiency in pursuit of its objectives. Viewed as an efficiency factor, the GPA is not affected by the duration of enrollment of the student at the university.

\section{Analysis}

Standard statistical analysis was used to calculate the correlation coefficient of each pair of results in the form of Spearman's " $\rho$ ". The value of student's " $t$ " was calculated for each correlation coefficient, using the approximate expression ${ }^{[1]}$ :

$$
t=\rho \cdot \sqrt{(N-2) /\left(1-\rho^{2}\right)}
$$

where $N=$ size of sample.

Single-tailed probability for values of " $t$ " more than the values obtained from using the above expression were calculated. Significance levels of $5 \%$ and $64 \%$ were used to test the hypothesis that there is no correlation between the variables. The $5 \%$ level test was carried out on the assumption that the basic data are reliable in statistical terms. The assumption of a far lesser degree of reliability of data accuracy underlie the use of the $64 \%$ level test ${ }^{[2]}$.

\section{Description of Results}

The basic data used and detailed analytical results for one college only are placed in the Appendix, as an example, and are described there. The following paragraphs 
describe the main results which are contained in Tables 1 to 6 . Numbers within the tables relating to college requirements are identified; dashes were placed where the information was not necessary for a particular college.

Table lists the admission requirements at twelve colleges. The main requirement is the attainment of a minimum GCE mark, or grade, and varies from $60 \%$ (Pharmacy) to $85 \%$ (Medicine). Six of the colleges impose additional subjects requirements, mainly in science subjects and English language.

TABLE 1. Admission requirements at some colleges of higher education.

\begin{tabular}{|c|c|c|c|}
\hline NAME OF COLLEGE & TYPE OF GCE* & $\begin{array}{l}\text { TOTAL } \\
\text { GCE } \\
\text { MARK. \% }\end{array}$ & $\begin{array}{l}\text { ADDITIONAL SUBJECT } \\
\text { REOUIREMENTS }\end{array}$ \\
\hline $\begin{array}{l}\text { Administrative } \\
\text { Sciences }\end{array}$ & Science or Arts & $\begin{array}{c}80 \% \text { Science } \\
80 \% \text { Arts }\end{array}$ & None \\
\hline Agriculture & Science & $75 \%$ & $\begin{array}{c}\text { Not less than } 70 \% \text { in } \\
\text { Physics, Chemistry, and } \\
\text { Biology }\end{array}$ \\
\hline $\begin{array}{l}\text { Architecture and } \\
\text { Planning }\end{array}$ & Science or Arts & $\begin{array}{l}70 \% \text { Science } \\
80 \% \text { Arts }\end{array}$ & $\begin{array}{c}\text { Not less than } 75 \% \text { in } \\
\text { Physics, Chemistry, and } \\
\text { Mathematics for Science } \\
\text { GCE }\end{array}$ \\
\hline Arts & Science or Arts & $75 \%$ & Variable \\
\hline Dentistry & Science & $80 \%$ & $\begin{array}{l}\text { Not less than } 80 \% \text { in } \\
\text { Physics, Chemistry, } \\
\text { Biology, and English }\end{array}$ \\
\hline Education & Science or Arts & $\begin{array}{l}65 \% \text { Science } \\
75 \% \text { Arts }\end{array}$ & None \\
\hline Engineering & Science & $75 \%$ & $\begin{array}{l}\text { Not less than } 75 \% \text { in } \\
\text { Physics, chemistry, and } \\
\text { Mathematics }\end{array}$ \\
\hline $\begin{array}{c}\text { Information \& } \\
\text { Computer Sciences }\end{array}$ & Science & $80 \%$ & None \\
\hline Medicine & Science & $85 \%$ & $\begin{array}{l}\text { Not less than } 80 \% \text { in } \\
\text { Physics. Chemistry, } \\
\text { Biology, and English }\end{array}$ \\
\hline Paramedical Studies & Science & $70 \%$ & None \\
\hline Pharmacy & Science & $60 \%$ & $\begin{array}{l}\text { Not less than } 70 \% \text { in } \\
\text { Physics, Chemistry, and } \\
\text { Biology }\end{array}$ \\
\hline Science & Science & $65 \%$ & None \\
\hline
\end{tabular}


Table 2 shows the number of data of finite values, described hereafter as "non-zero students' marks", used in the analyses and the various subjects and combinations of subjects which were considered. The apparent discrepancies in the number of nonzero students' marks used in the analyses are mainly due to the following :

a) Zero values for GPA which resulted in the reduction of the sample for the Colleges of Education and Medicine.

b) Non availability of GCE diplomas.

c) Non uniformity in the presentation of information in GCE diplomas issued by various educational authorities.

TABLE 2. Number of non-zero students' marks analyzed.

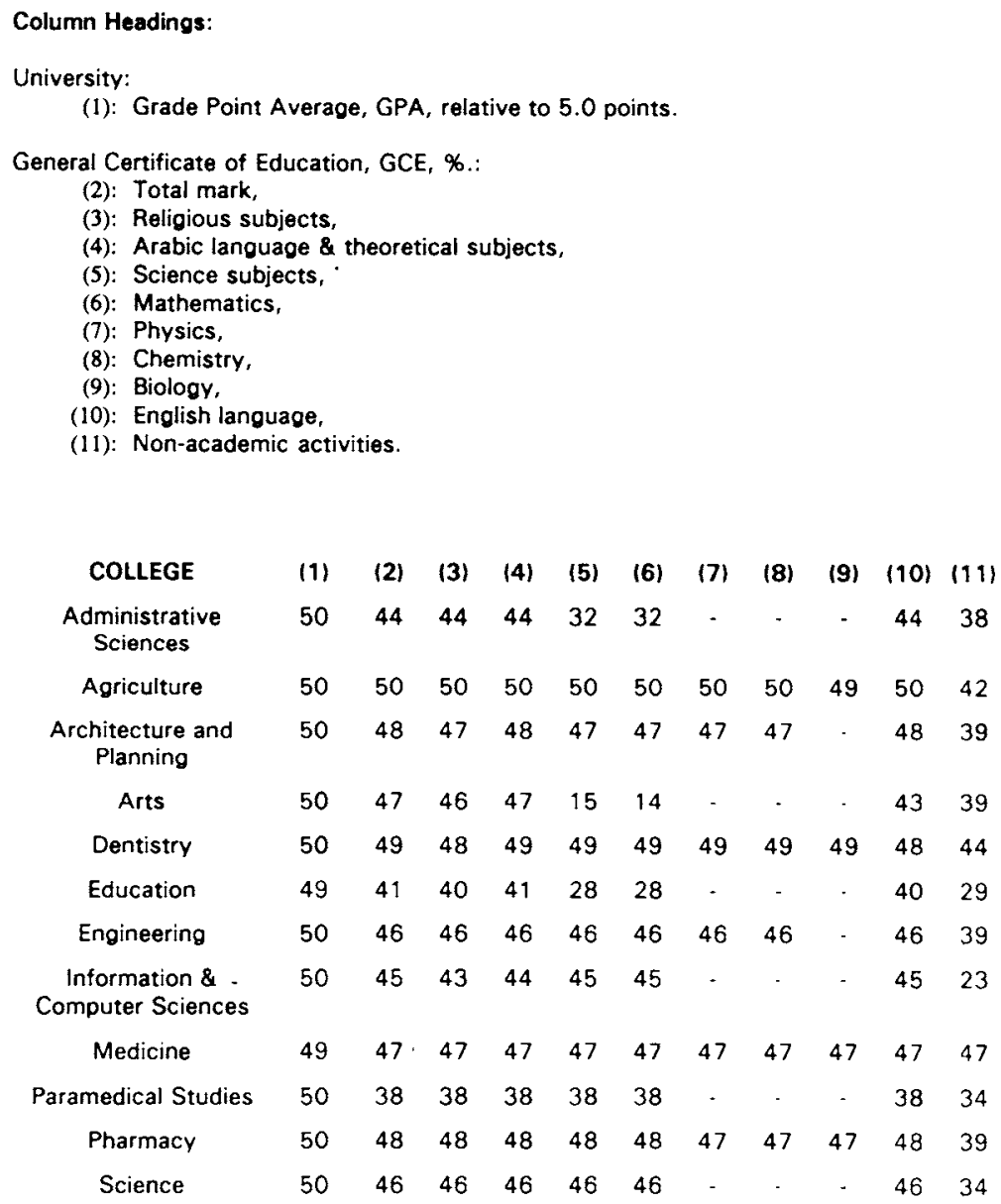


Table 3 shows the degree of compliance with admission requirements in both the general and additional requirements. The Table is self-explanatory.

TABLE 3. Percentages of admissions with marks below minimum requirements.

$\begin{array}{ccccccc}\text { COLLEGE } & \begin{array}{c}\text { Total } \\ \text { GCE }\end{array} & \begin{array}{c}\text { Mathem- } \\ \text { atics }\end{array} & \text { Physics } & \text { Chemistry } & \text { Biology } & \text { English } \\ \begin{array}{c}\text { Administrative } \\ \text { Sciences }\end{array} & 70 & - & - & - & - & - \\ \begin{array}{c}\text { Agriculture } \\ \text { Architecture and } \\ \text { Planning }\end{array} & 64 & - & 74 & 70 & 29 & - \\ \quad \text { Arts } & 53 & 32 & 57 & 47 & - & - \\ \begin{array}{c}\text { Dentistry } \\ \text { Education }\end{array} & 57 & - & - & - & - & - \\ \text { Engineering } & 17 & - & - & - & - & - \\ \text { Information \& } & 7 & 13 & 35 & 46 & - & - \\ \text { Computer Sciences } & 62 & - & - & - & - & - \\ \text { Medicine } & 28 & - & 40 & 32 & 13 & 47 \\ \text { Paramedical Studies } & 24 & - & - & - & - & - \\ \text { Pharmacy } & 0 & - & 62 & 66 & 30 & - \\ \quad \text { Science } & 15 & - & - & - & - & -\end{array}$

Table 4 shows the mean values of GPA's and marks obtained in various subjects of the GCE. It is to be noted that the average mark for Mathematics $(68 \%)$ was obtained in the GCE by students of the Colleges of Art and Science. It is to be noted also that relatively high marks are given to students for non academic activities; inclusion of marks for these in the total GCE marks adds to it $2 \%$ to $3 \%$.

Table 5 shows values of standard deviation for the marks used in the analyses and indicate the degree of dispersion of the marks. Thus, the GCE marks for mathematics of two thirds of the students of the College of Arts were in the range 56-80\%. On the other hand, the marks for mathematics for a similar proportion of the students of the College of Science were in the range $53-83 \%$. Thus, assuming normal contributions of GCE results, a major proportion of the students of the Colleges of Arts and Science have comparable mathematical abilities. The College of Arts, however, does not include mathematics in its curricula. Languages, however, as structured forms of communications, are amenable to mathematical analysis, and may benefit from the use of mathematical logic.

Table 6 indicates the existence, or non existence, of correlation between the GPA and GCE results at two levels of significance: $5 \%$ and $64 \%$. The results show that, with few exceptions (Colleges of Arts, Education, and Paramedical Studies), there is no correlation between GCE marks and GPA using a 5\% significance level. It also 
TABLE 4. Mean values of grade point averages and GCE marks.

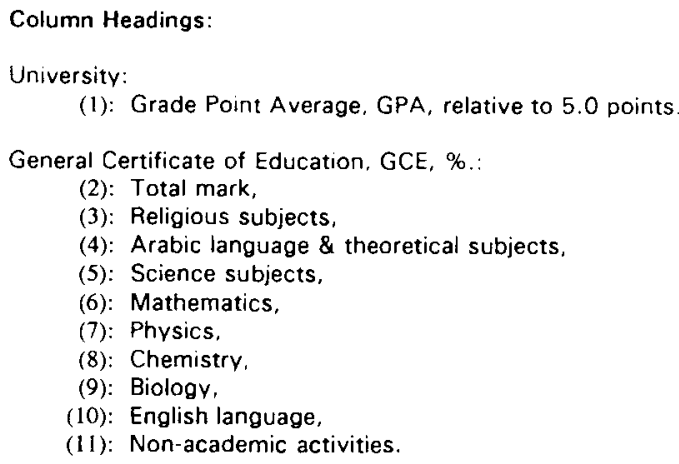

\begin{tabular}{|c|c|c|c|c|c|c|c|c|c|c|}
\hline COLLEGE & (1) & (2) & (3) & (4) & (5) & (6) & (7) & (8) & (9) & $(10)$ \\
\hline $\begin{array}{l}\text { Administrative } \\
\text { Sciences }\end{array}$ & 2.14 & $76^{\circ}$ & 78 & 75 & 71 & 72 & & - & & 69 \\
\hline Agriculture & 2.39 & $73^{\circ}$ & 76 & 71 & 70 & 71 & $65^{\circ}$ & $66^{\circ}$ & $73^{*}$ & 65 \\
\hline $\begin{array}{l}\text { Architecture and } \\
\text { Planning }\end{array}$ & 2.90 & $79^{\circ}$ & 83 & 79 & 76 & $78^{\circ}$ & $73^{\circ}$ & $74^{\circ}$ & - & 75 \\
\hline Arts & 2.38 & $74^{\circ}$ & 78 & 75 & 65 & 68 & - & - & - & 66 \\
\hline Dentistry & 3.07 & $78^{\circ}$ & 83 & 76 & 78 & 77 & $73^{\circ}$ & $76^{\circ}$ & $82^{\circ}$ & 71 \\
\hline Education & 2.36 & $72^{\circ}$ & 79 & 71 & 67 & 69 & $\cdot$ & - & - & 63 \\
\hline Engineering & 2.41 & $83^{\circ}$ & 85 & 81 & 81 & $83^{\circ}$ & $78^{\circ}$ & $77^{\circ}$ & - & 74 \\
\hline $\begin{array}{c}\text { Information \& } \\
\text { Computer Sciences }\end{array}$ & 2.81 & $76^{\circ}$ & 81 & 73 & 73 & 80 & - & - & - & 66 \\
\hline Medicine & 2.84 & $87^{\circ}$ & 91 & 87 & 85 & 86 & $80^{\circ}$ & $81^{\circ}$ & $89^{\circ}$ & $80^{\circ}$ \\
\hline Paramedical Studies & 2.64 & $75^{\circ}$ & 80 & 76 & 71 & 73 & - & - & - & 68 \\
\hline Pharmacy & 2.74 & $77^{\circ}$ & 83 & 75 & 75 & 75 & $71^{\circ}$ & $71^{\circ}$ & $80^{\circ}$ & 71 \\
\hline Science & 2.28 & $73^{\circ}$ & 77 & 73 & 70 & 68 & - & . & & 68 \\
\hline
\end{tabular}

Note: $\mathrm{NN}^{*}$ for subject required by college - compare with figures shown in Table 1.

shows that, except for the Colleges of Agriculture and Engineering, there is correlation between GCE marks and GPA using a significance level of $64 \%$. It is to be noted that a negative correlation indicates an inverse relationship.

\section{Comments, Recommendations and Conclusions}

The investigation revealed that, to a large extent, existing admission requirements are not adhered to. Whether this non adherence has adverse effect on higher education or not is a matter of conjecture. The origins and objectives of the conditions are 
TABLE 5. Values of standard deviation.

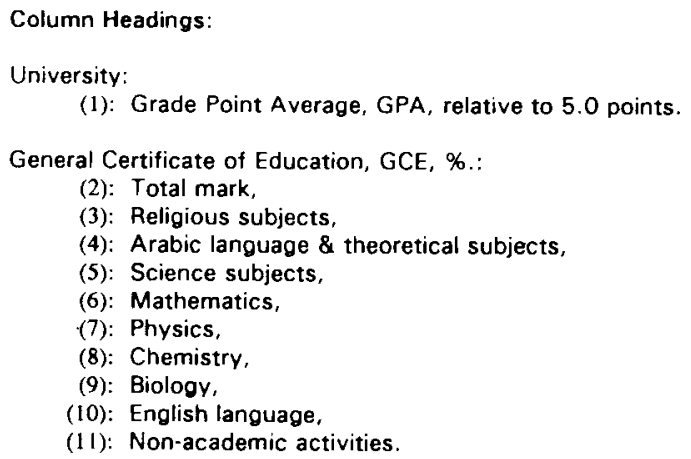

$\begin{array}{cccccccccccc}\text { COLLEGE } & (1) & (2) & (3) & (4) & (5) & (6) & (7) & (8) & (9) & (10) & (11) \\ \begin{array}{c}\text { Administrative } \\ \text { Sciences }\end{array} & 0.35 & 8 & 10 & 10 & 9 & 14 & - & - & - & 13 & 5 \\ \begin{array}{c}\text { Agriculture } \\ \text { Architecture and } \\ \text { Planning }\end{array} & 0.48 & 8 & 9 & 10 & 9 & 12 & 10 & 10 & - & 10 & 4 \\ \text { Arts } & 0.65 & 8 & 11 & 10 & 9 & 10 & 12 & 10 & - & 11 & 4 \\ \text { Dentistry } & 0.51 & 6 & 8 & 7 & 17 & 12 & 0 & 0 & - & 13 & 6 \\ \text { Education } & 0.44 & 11 & 8 & 8 & 8 & 10 & 11 & 10 & 10 & 11 & 6 \\ \text { Engineering } & 0.53 & 10 & 8 & 11 & 13 & 13 & - & - & - & 13 & 6 \\ \text { Information \& } & 0.52 & 6 & 7 & 9 & 8 & 7 & 10 & 11 & - & 14 & 3 \\ \text { Computer Sciences } & 0.77 & 9 & 9 & 10 & 12 & 15 & - & - & - & 18 & 3 \\ \text { Medicine } & 0.65 & 6 & 5 & 6 & 8 & 9 & 11 & 11 & - & 9 & 2 \\ \text { Paramedical Studies } & 0.60 & 8 & 9 & 9 & 9 & 11 & - & - & - & 14 & 3 \\ \text { Pharmacy } & 0.66 & 8 & 8 & 10 & 8 & 12 & 12 & 11 & - & 9 & 5 \\ \text { Science } & 0.52 & 8 & 10 & 9 & 9 & 15 & . & - & - & 14 & 6\end{array}$

themselves not clear. It is not clear, for example, why the total GCE mark is given precedence over specialized subjects in terms of admission. This stipulation appears to lead to the loss of high quality students, from an academic standpoint, due to their inability to obtain high total GCE marks. If, as is more likely, the distribution of GCE marks on the various subjects indicates a student's natural tendency and ability, the admission requirements must ensure the enrollment of students having the highest possible marks in the specialized subjects. Here the total GCE mark, less marks for non academic activities, should be given a secondary place. It is recognized, however, that regulations, and the effort put into formulating them, are worthless without the will, or ability, to carry them out. In such circumstances, ran- 
TABLE 6. Correlation table for GPA and GCE marks for subjects required for admission to colleges.

\begin{tabular}{|c|c|c|c|c|c|c|c|c|c|c|c|c|}
\hline \multirow[t]{2}{*}{ COLLEGE } & \multicolumn{2}{|c|}{$\begin{array}{l}\text { Total } \\
\text { GCE }\end{array}$} & \multicolumn{2}{|c|}{$\begin{array}{l}\text { Mathom- } \\
\text { otice }\end{array}$} & \multicolumn{2}{|c|}{ Phyaice } & \multicolumn{2}{|c|}{ Chomietry } & \multicolumn{2}{|c|}{ Biology } & \multicolumn{2}{|c|}{ English } \\
\hline & $5 \%$ & $64 \%$ & $5 \%$ & $64 \%$ & $5 \%$ & $64 \%$ & $5 \%$ & $64 \%$ & $5 \%$ & $64 \%$ & $5 \%$ & $64 \%$ \\
\hline Administretive Sciences & NC & $+\mathrm{C}$ & - & . & . & - & - & . & - & - & - & . \\
\hline Agriculture & NC & NC & - & . & NC & $+\mathrm{C}$ & NC & NC & NC & $-\mathrm{C}$ & - & - \\
\hline Architecture and Planning & NC & $+c$ & NC & $+c$ & NC & $+\mathrm{C}$ & NC & $+c$ & - & - & . & - \\
\hline Arts & $+\mathrm{C}$ & $+\mathrm{C}$ & - & - & - & - & . & - & - & . & - & . \\
\hline Dentistry & NC & $-c$ & - & . & NC & $c$ & NC & $-\mathrm{C}$ & NC & $+\mathrm{C}$ & NC & $+\mathrm{C}$ \\
\hline Education & $+c$ & $+c$ & - & . & . & . & - & - & . & . & - & . \\
\hline Engineoring & NC & NC & NC & $+c$ & NC & NC & NC & NC & - & . & - & . \\
\hline $\begin{array}{l}\text { Information \& Computer } \\
\text { Scionces }\end{array}$ & NC & $+c$ & - & . & - & - & - & - & - & . & . & - \\
\hline Modicino & NC & $+C$ & $\cdot$ & . & NC & $+C$ & NC & $+C$ & NC & NC & NC & $-c$ \\
\hline Paramodical Studies & $+\mathrm{C}$ & $+C$ & - & . & - & - & - & . & - & . & $\cdot$ & - \\
\hline Pharmecy & NC & $+C$ & . & - & NC & $+\mathrm{C}$ & NC & $+C$ & NC & $+c$ & - & - \\
\hline Science & NC & $+C$ & . & . & - & - & . & . & . & . & - & - \\
\hline
\end{tabular}

dom selection may be a better choice and various methods, giving fair and equitable chances to all applicants, can be devised and implemented. An alternative, perhaps for future consideration, is the establishment of fees for higher education with proper safeguards and sound basis for a system of grants, from official and private bodies, for the benefit of students needing financial help.

The correlation between GCE marks and GPA was almost non existent. The $64 \%$ level of significance represents a very high degree of uncertainty and is not likely to be the result of inconsistent evaluation at schools. Correlation tables (Tables 4A \& $5 \mathrm{~A}$, Appendix) indicate almost complete correlation, at $5 \%$ and $64 \%$ significance levels, between the marks obtained in various subjects at the GCE level. It is more likely that evaluation at university level is the source of such a high degree of uncertainty.

It is clear that institutions of general and university education are separate entities, having separate environments, with obvious boundaries. Teaching methods, level of maturity and mental attitude, parental supervision, personal awareness and independence are all expressed and experienced differently in those two environments. Thus, the transfer from one environment to the other is not a smooth transition but, to many students, a bewildering leap into the unknown. To achieve a smooth transition from one system to the other, there is a need for consciously formulated policy to blur the boundaries between them. A gradual change of teaching methods and 
educational attitudes can be adopted during the last phases of general education. Such a policy may help to bridge the gap between the environments in the two systems. Unification of the two systems under a single active policy-making and controlling authority would help to achieve the same objective more efficiently.

Returning to the question posed earlier in the Introduction. Can expectations be properly based on extrapolation of records of past performance in the dynamic state of development? The results of the investigation lead to two conclusions. First, if the basic information used is assumed to be correct, then the answer to the question stated above is negative; different admission requirements have to be devised and justified. Second, if the basic information is assumed to contain a large element of uncertainty as suggested by an earlier investigation ${ }^{[2]}$, then the answer is, to a large extent, positive; steps have to be taken to reduce the uncertainty (Table 6). Acceptance of either conclusion is, therefore, dependent upon confidence in the evaluation of the academic records which, itself, is related to the experience and wisdom of the academic staff.

Although the investigation is based on conditions at one university, its conclusions are applicable to other universities where similar conditions may prevail.

\section{Acknowledgment}

The Author expresses his thanks and gratitude to those who have kindly provided the information used in this investigation. Sincere thanks are also expressed to friends and colleagues for their advice and suggestions.

Thanks are also expressed to the academic councils and administrative authorities of King Saud University for granting the Author a sabbatical leave to carry out this investigation, which was completed on the 15 th of Jumada Al Awwal 1407 A.H. (December 16, 1986 A.D.), and other investigations of educational and organizational relevance.

\section{Appendix}

\section{Explanatory Notes}

The Appendix consists of seven tables containing, as examples, the basic data used and analytical results for one college. Description of the contents and the method by which the figures were arrived at are described below.

Table 1A: Contains the basic information used in the investigation and results of the analyses. These . are :

a) The Grade Point Average, GPA, relative to 5.0 points for each student.

b) The percentages obtained in the General Certificate of Education, GCE, in subjects required by the college. 
c) Marks, \% obtained in groups of similar subjects. Where a student obtained the GCE from a comprehensive school, his GPA, represented by the grade he obtained, was converted to percentage points by use of the relationship which is presented graphically in Fig. 1:

$$
M=16.21+32.35 \cdot G-6.57 \cdot G^{2}+0.68 \cdot G^{3}
$$

where $M=\operatorname{mark}(\%)$, and $G=\mathrm{GPA} \geq 2.00$ and $\mathrm{GPA} \leq 5.0$

Table 2A: Contains Spearman's correlation coefficient. " $\rho$ ", for the various combinations of the results excluding zero values.

Table 3A: Contains Student 's " $t$ " for each value of " $\rho$ " calculated using the approximate relationship:

$$
t=\rho \cdot \sqrt{(N-2) /\left(1-\rho^{2}\right)}
$$

Table 4A: Contains single-tailed probability values for " $"$ " exceeding the values in Table $3 \mathrm{~A}$

Table 5A: Contains a symbolic presentation of existence, or otherwise, of correlation between the various combinations of results based on a $5 \%$ significance level.

Table 6A: Similar to Table 5A except that the level of significance used was $64 \%$

Table 7A: Contains the number of pairs of non-zero results in each combination; these are the pairs which were analyzed statistically.

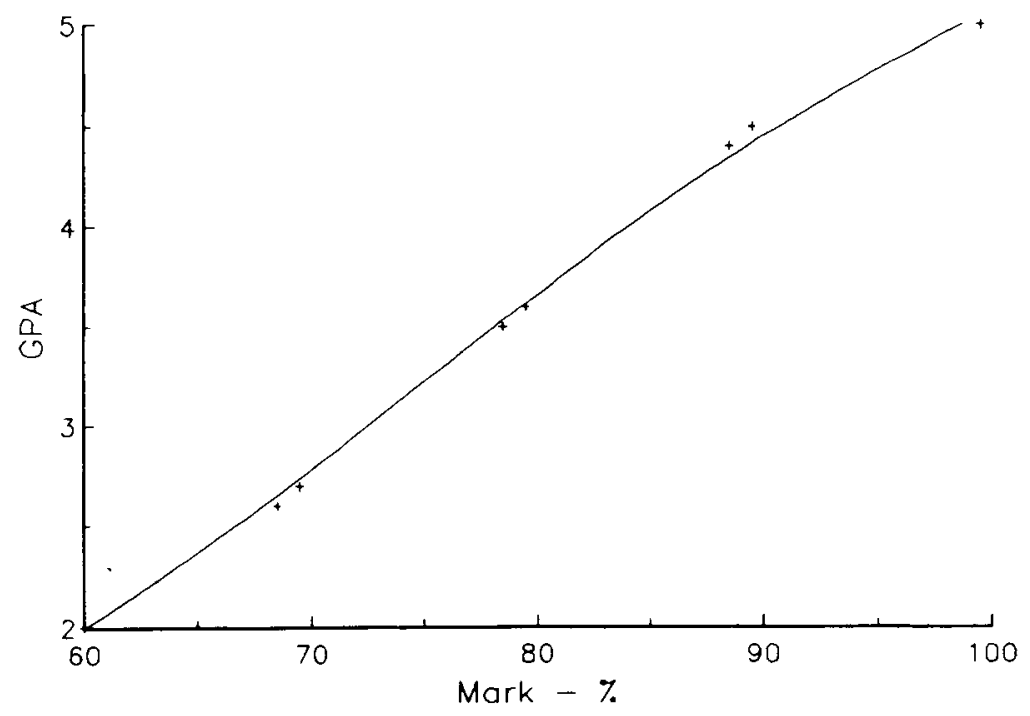

FIG. 1. GPA-Mark (\%) 
TABLE 1A. GPA \& GCE Marks.

\section{College of Engineering}

Table Headings:

(11: GPA rolotive to 5.0 points.

(2): Total GCE mark, \%.

(3): Roligious Subjocts, \%.

(4): Arabic Language \& Theoretical Subjects, $\%$.

(6): Mathematics, \%.

(7): Physics, \%

(5): Science Subjects, \%.

(9): English Languago, $\%$.

(10): Non-Acodemic activity, \%

\begin{tabular}{|c|c|c|c|c|c|c|c|c|c|c|}
\hline No. & (1) & (2) & (3) & (4) & (5) & (6) & (7) & (8) & $(\langle 9)$ & (10) \\
\hline 1 & 2.87 & 91 & 96 & 88 & 89 & 96 & 86 & 92 & 72 & 100 \\
\hline 2 & 2.23 & 87 & 94 & 94 & 87 & 79 & 82 & 81 & 81 & 97 \\
\hline 3 & 2.33 & 90 & 87 & 93 & 87 & 93 & 83 & 89 & 90 & 89 \\
\hline 4 & 1.99 & 94 & 88 & 88 & 96 & 96 & 95 & 95 & 92 & - \\
\hline 5 & 2.27 & - & - & - & - & - & - & - & - & - \\
\hline 6 & 1.98 & 84 & 89 & 82 & 80 & 84 & 78 & 66 & 75 & 99 \\
\hline 7 & 2.29 & 85 & 85 & 90 & 83 & 83 & 83 & 65 & 81 & 97 \\
\hline 8 & 2.29 & 80 & 79 & 81 & 77 & 80 & 70 & 69 & 72 & 97 \\
\hline 9 & 1.89 & 81 & 75 & 73 & 86 & 84 & 81 & 82 & 79 & 97 \\
\hline 10 & 2.65 & 81 & 87 & 79 & 74 & 86 & 62 & 60 & 55 & 98 \\
\hline 11 & 2.47 & - & - & - & - & - & - & - & - & - \\
\hline 12 & 2.30 & - & - & - & - & - & - & - & - & - \\
\hline 13 & 2.46 & - & - & - & - & - & - & - & - & - \\
\hline 14 & 2.24 & 87 & 80 & 84 & 83 & 96 & 97 & 97 & 86 & - \\
\hline 15 & 2.05 & 83 & 88 & 81 & 79 & 76 & 71 & 71 & 16 & - \\
\hline 16 & 2.19 & 83 & 80 & 76 & 83 & 85 & 76 & 82 & 74 & 99 \\
\hline 17 & 2.00 & 89 & 95 & 88 & 86 & 84 & 79 & 84 & 87 & 99 \\
\hline 18 & 2.40 & 75 & 77 & 68 & 73 & 70 & 71 & 69 & 60 & 100 \\
\hline 19 & 2.09 & 89 & 91 & 84 & 90 & 84 & 87 & 89 & 91 & 100 \\
\hline 20 & 2.27 & 85 & 89 & 83 & 76 & 93 & 81 & 50 & 86 & 98 \\
\hline 21 & 2.28 & 77 & 81 & 72 & 72 & 77 & 54 & 70 & 78 & 96 \\
\hline 22 & 1.95 & 89 & 91 & 90 & 89 & 84 & 89 & 86 & 82 & 98 \\
\hline 23 & 2.05 & 79 & 83 & 82 & 72 & 83 & 78 & 72 & 67 & 97 \\
\hline 24 & 2.16 & 81 & 81 & 86 & 75 & 82 & 74 & 69 & 82 & 95 \\
\hline 25 & 2.43 & 85 & 89 & 84 & 86 & 81 & 81 & 81 & 76 & 97 \\
\hline 20 & 2.12 & 76 & 91 & 62 & 90 & 72 & 95 & 83 & 50 & - \\
\hline 27 & 2.28 & 97 & 98 & 94 & 99 & 96 & 99 & 99 & 97 & 100 \\
\hline 28 & 2.67 & 87 & 83 & 88 & 91 & 87 & 85 & 92 & 82 & 97 \\
\hline 29 & 2.33 & 75 & 75 & 74 & 76 & 77 & 85 & 68 & 69 & - \\
\hline 30 & 2.29 & 81 & 79 & 86 & 81 & 73 & 75 & 87 & 80 & 97 \\
\hline 31 & 2.17 & 86 & 90 & 90 & 84 & 84 & 73 & 80 & 73 & 95 \\
\hline 32 & 2.06 & 74 & 85 & 67 & 70 & 66 & 65 & 67 & 67 & 100 \\
\hline 33 & 2.83 & 87 & 89 & 85 & 86 & 88 & 90 & 77 & 82 & 97 \\
\hline 34 & 2.29 & 81 & 92 & 87 & 83 & 70 & 75 & 91 & 60 & - \\
\hline 35 & 3.48 & 83 & 82 & 78 & 85 & 84 & 84 & 73 & 71 & 100 \\
\hline 36 & 3.24 & 90 & 97 & 91 & 89 & 84 & 75 & 91 & 85 & 95 \\
\hline 37 & 2.50 & 84 & 83 & 87 & 81 & 84 & 81 & 82 & 83 & 97 \\
\hline 38 & 2.69 & 83 & 91 & 81 & 74 & 82 & 62 & 75 & 87 & 100 \\
\hline 39 & 2.33 & 78 & 79 & 75 & 74 & 82 & 79 & 70 & 72 & 96 \\
\hline 40 & 2.74 & 86 & 83 & 76 & 88 & 92 & 86 & 81 & 81 & 100 \\
\hline 41 & 2.13 & 87 & 86 & 91 & 87 & 87 & 83 & 91 & 77 & 96 \\
\hline 42 & 2.53 & 78 & 71 & 73 & 75 & 86 & 73 & 77 & 73 & 96 \\
\hline 43 & 3.16 & 84 & 80 & 67 & 76 & 80 & 72 & 67 & 56 & 99 \\
\hline 44 & 2.30 & 86 & 91 & 90 & 83 & 83 & 81 & 76 & 80 & 97 \\
\hline 45 & 2.77 & 73 & 82 & 70 & 67 & 75 & 65 & 63 & 63 & 84 \\
\hline 46 & 2.98 & 69 & 70 & 59 & 69 & 73 & 71 & 74 & 63 & - \\
\hline 47 & 2.26 & 81 & 92 & 89 & 71 & 81 & 68 & 65 & 72 & 95 \\
\hline 48 & 2.25 & 76 & 84 & 69 & 69 & 79 & 65 & 70 & 63 & 96 \\
\hline 49 & 2.44 & 82 & 87 & 84 & 76 & 78 & 70 & 74 & 74 & 99 \\
\hline so & 3.75 & 83 & 84 & 81 & 80 & 86 & 82 & 72 & 75 & 99 \\
\hline
\end{tabular}


TABI.E 2A. Spcarman's correlation coefficients.

\section{College of Engineering}

Tabie Column and Row Headings:
(1): GPA
(2): Total GCE mark
(3): Religious Subjects
(4): Arabic Language \& Theoretical Subjects
(5): Science Subjects

(6): Mathematics

(7): Physics

(8): Chemistry

(9): English Language

(10): Non-Academic activity

$\begin{array}{cccccccccc}(1) & (2) & (3) & (4) & (5) & (6) & (7) & (8) & (9) & (10) \\ - & -0.066 & -0.172 & -0.155 & -0.134 & 0.053 & -0.103 & -0.106 & -0.136 & 0.103 \\ -0.066 & - & 0.607 & 0.783 & 0.809 & 0.730 & 0.635 & 0.630 & 0.723 & 0.187 \\ -0.172 & 0.607 & - & 0.630 & 0.483 & 0.211 & 0.236 & 0.315 & 0.316 & 0.165 \\ -0.155 & 0.783 & 0.630 & - & 0.591 & 0.455 & 0.413 & 0.499 & 0.622 & -0.198 \\ -0.134 & 0.809 & 0.483 & 0.591 & - & 0.549 & 0.804 & 0.784 & 0.541 & 0.214 \\ 0.053 & 0.730 & 0.211 & 0.455 & 0.549 & - & 0.587 & 0.434 & 0.607 & 0.164 \\ -0.103 & 0.635 & 0.236 & 0.413 & 0.804 & 0.587 & - & 0.600 & 0.490 & 0.258 \\ -0.106 & 0.630 & 0.315 & 0.499 & 0.784 & 0.434 & 0.600 & - & 0.501 & 0.093 \\ -0.136 & 0.723 & 0.316 & 0.622 & 0.541 & 0.607 & 0.490 & 0.501 & - & 0.044 \\ 0.103 & 0.187 & 0.165 & -0.198 & 0.214 & 0.164 & 0.258 & 0.093 & 0.044 & -\end{array}$

TABLI: 3A. Values of student's " $7 "$.

\section{College of Engineering}

Table Column and Row Headings:
(1): GPA
(2): Total GCE mark
(3): Religious Subjects
14): Arabic Language \& Theoretical Subjects
(5): Science Subjects

(6): Mathematics

(7): Physics

(9): English Language

(10): Non-Academic activity

(8): Chemistry

$\begin{array}{rcccccccccc} & (1) & (2) & (3) & (4) & (5) & (6) & (7) & (8) & (9) & (10) \\ (1) & - & -0.441 & -1.156 & -1.040 & -0.894 & 0.354 & -0.688 & 0.705 & -0.908 & 0.627 \\ (2) & -0.441 & - & 5.071 & \mathbf{8 . 3 5 4} & \mathbf{9 . 1 1 7} & 7.095 & 5.445 & 5.379 & 6.936 & 1.156 \\ (3) & -1.156 & 5.071 & - & 5.386 & 3.662 & 1.430 & 1.610 & 2.205 & 2.209 & 1.017 \\ (4) & -1.040 & \mathbf{8 . 3 5 4} & 5.386 & - & 4.862 & 3.387 & 3.007 & 3.818 & 5.268 & -1.230 \\ (5) & -0.894 & 9.117 & 3.662 & 4.862 & - & 4.361 & 8.968 & 8.371 & 4.263 & 1.330 \\ (6) & 0.354 & 7.095 & 1.430 & 3.387 & 4.361 & - & 4.814 & 3.196 & 5.069 & 1.009 \\ (7) & -0.688 & 5.445 & 1.610 & 3.007 & 8.968 & 4.814 & - & 4.976 & 3.726 & 1.627 \\ (8) & -0.705 & 5.379 & 2.205 & 3.818 & 8.371 & 3.196 & 4.976 & - & 3.835 & 0.570 \\ (9) & -0.908 & 6.936 & 2.209 & 5.268 & 4.263 & 5.069 & 3.726 & 3.835 & - & 0.270 \\ (10) & 0.627 & 1.156 & 1.017 & -1.230 & 1.330 & 1.009 & 1.627 & 0.570 & 0.270 & -\end{array}$


TABLE 4A. Values of single-tailed probability

\section{College of Engineering}

Table Column and Row Headings:
(1): GPA
(2): Total GCE mark
(3): Roligious Subjocts
(4): Arabic Lenguage \& Theoretical Subjects
5): Science Subjects
(6): Mathematics
(7): Physics
(9): English Languago
(10): Non-Academic activity
(8): Chemistry

$\begin{array}{ccccccccccc} & (1) & (2) & (3) & (4) & (5) & (6) & (7) & (8) & (9) & (10) \\ (1) & - & 0.889 & 0.873 & 0.848 & 0.812 & 0.362 & 0.753 & 0.758 & 0.816 & 0.267 \\ (2) & 0.669 & - & 0.000 & 0.000 & 0.000 & 0.000 & 0.000 & 0.000 & 0.000 & 0.127 \\ (3) & 0.873 & 0.000 & - & 0.000 & 0.000 & 0.080 & 0.057 & 0.016 & 0.016 & 0.158 \\ (4) & 0.848 & 0.000 & 0.000 & - & 0.000 & 0.001 & 0.002 & 0.000 & 0.000 & 0.887 \\ (5) & 0.812 & 0.000 & 0.000 & 0.000 & - & 0.000 & 0.000 & 0.000 & 0.000 & 0.096 \\ (6) & 0.362 & 0.000 & 0.080 & 0.001 & 0.000 & - & 0.000 & 0.001 & 0.000 & 0.159 \\ (7) & 0.753 & 0.000 & 0.057 & 0.002 & 0.000 & 0.000 & - & 0.000 & 0.000 & 0.056 \\ (8) & 0.758 & 0.000 & 0.016 & 0.000 & 0.000 & 0.001 & 0.000 & - & 0.000 & 0.286 \\ (9) & 0.816 & 0.000 & 0.016 & 0.000 & 0.000 & 0.000 & 0.000 & 0.000 & - & 0.394 \\ (10) & 0.267 & 0.127 & 0.158 & 0.887 & 0.096 & 0.159 & 0.056 & 0.286 & 0.394 & -\end{array}$

TABLF 5A. Correlation table for a $5 \%$, significance level.

\section{College: Engineering}

Table Column and Row Headings:

(1): GPA

(4): Arabic Languege \& Theoretical Subjects

(6): Mathematics

(9): English Languago

$\begin{array}{lrrr} & (1) & (2) & (3) \\ (1) & - & N C & N C \\ (2) & N C & - & +C \\ (3) & N C & +C & - \\ (4) & N C & +C & +C \\ (5) & N C & +C & +C \\ (6) & N C & +C & N C \\ (7) & N C & +C & N C \\ (8) & N C & +C & +C \\ (9) & N C & +C & +C \\ (10) & \text { NC } & \text { NC } & \text { NC }\end{array}$

$+C=$ positive corrolation,

- $\mathrm{C}=$ negative corrolation

$\mathrm{NC}=$ no correlation.
(3): Religious Subjects

(5): Scionce Subjects

(8): Chemistry

(7): Physics

(10): Non-Acadomic activity

$\begin{array}{rrrrrrr}(4) & (5) & (6) & (7) & (8) & (9) & (10) \\ \mathrm{NC} & \mathrm{NC} & \mathrm{NC} & \mathrm{NC} & \mathrm{NC} & \mathrm{NC} & \mathrm{NC} \\ +\mathrm{C} & +\mathrm{C} & +\mathrm{C} & +\mathrm{C} & +\mathrm{C} & +\mathrm{C} & \mathrm{NC} \\ +\mathrm{C} & +\mathrm{C} & \mathrm{NC} & \mathrm{NC} & +\mathrm{C} & +\mathrm{C} & \mathrm{NC} \\ - & +\mathrm{C} & +\mathrm{C} & +\mathrm{C} & +\mathrm{C} & +\mathrm{C} & \mathrm{NC} \\ +\mathrm{C} & - & +\mathrm{C} & +\mathrm{C} & +\mathrm{C} & +\mathrm{C} & \mathrm{NC} \\ +\mathrm{C} & +\mathrm{C} & - & +\mathrm{C} & +\mathrm{C} & +\mathrm{C} & \mathrm{NC} \\ +\mathrm{C} & +\mathrm{C} & +\mathrm{C} & - & +\mathrm{C} & +\mathrm{C} & \mathrm{NC} \\ +\mathrm{C} & +\mathrm{C} & +\mathrm{C} & +\mathrm{C} & - & +\mathrm{C} & \mathrm{NC} \\ +\mathrm{C} & +\mathrm{C} & +\mathrm{C} & +\mathrm{C} & +\mathrm{C} & - & \mathrm{NC} \\ \mathrm{NC} & \mathrm{NC} & \mathrm{NC} & \mathrm{NC} & \mathrm{NC} & \mathrm{NC} & -\end{array}$


TABLE 6A. Correlation table for a $64 \%$ significance level.

\section{College: Engineering}

Table Column and Row Headings:
(1): GPA
(2): Total GCE mark
(3): Religious Subjects
(4): Arabic Language \& Theoretical Subjects
(5): Science Subjects
(6): Mathematics
(7): Physics
(8): Chemistry
(10): Non-Academic activity

(9): English Language

$\begin{array}{lllllllllll} & (1) & (2) & (3) & (4) & (5) & (6) & (7) & (8) & (9) & (10) \\ (1) & - & N C & N C & N C & N C & +C & N C & N C & N C & +C \\ (2) & N C & - & +C & +C & +C & +C & +C & +C & +C & +C \\ (3) & N C & +C & - & +C & +C & +C & +C & +C & +C & +C \\ (4) & N C & +C & +C & - & +C & +C & +C & +C & +C & N C \\ (5) & N C & +C & +C & +C & - & +C & +C & +C & +C & +C \\ (6) & +\mathrm{C} & +\mathrm{C} & +\mathrm{C} & +\mathrm{C} & +\mathrm{C} & - & +\mathrm{C} & +\mathrm{C} & +\mathrm{C} & +\mathrm{C} \\ (7) & \mathrm{NC} & +\mathrm{C} & +\mathrm{C} & +\mathrm{C} & +\mathrm{C} & +\mathrm{C} & - & +\mathrm{C} & +\mathrm{C} & +\mathrm{C} \\ (8) & \mathrm{NC} & +\mathrm{C} & +\mathrm{C} & +\mathrm{C} & +\mathrm{C} & +\mathrm{C} & +\mathrm{C} & - & +\mathrm{C} & +\mathrm{C} \\ (9) & \mathrm{NC} & +\mathrm{C} & +\mathrm{C} & +\mathrm{C} & +\mathrm{C} & +\mathrm{C} & +\mathrm{C} & +\mathrm{C} & - & +\mathrm{C} \\ (10) & +\mathrm{C} & +\mathrm{C} & +\mathrm{C} & \mathrm{NC} & +\mathrm{C} & +\mathrm{C} & +\mathrm{C} & +\mathrm{C} & +\mathrm{C} & -\end{array}$

$+C=$ positive correlation

$C=$ negative correlation

$\mathrm{NC}=$ no correlation

TABLE 7A. Number of paired non-zero students' marks.

\section{College of Engineering}

Table Column and Row Headings:
(1): GPA
(2): Total GCE mark
(3): Religious Subjects
(4): Arabic Language \& Theoretical Subjects
: Science Subjects
(6): Mathematics
(7): Physics
(9): English Language
(10): Non-Academic activity
(8): Chemistry

$\begin{array}{rrrrrrrrrrr} & (1) & (2) & (3) & (4) & (5) & (6) & (7) & (8) & (9) & (10) \\ (1) & - & 46 & 46 & 46 & 46 & 46 & 46 & 46 & 46 & 39 \\ (2) & 46 & - & 46 & 46 & 46 & 46 & 46 & 46 & 46 & 39 \\ (3) & 46 & 46 & - & 46 & 46 & 46 & 46 & 46 & 46 & 39 \\ (4) & 46 & 46 & 46 & - & 46 & 46 & 46 & 46 & 46 & 39 \\ (5) & 46 & 46 & 46 & 46 & - & 46 & 46 & 46 & 46 & 39 \\ (6) & 46 & 46 & 46 & 46 & 46 & - & 46 & 46 & 46 & 39 \\ (7) & 46 & 46 & 46 & 46 & 46 & 46 & - & 46 & 46 & 39 \\ (8) & 46 & 46 & 46 & 46 & 46 & 46 & 46 & - & 46 & 39 \\ (9) & 46 & 46 & 46 & 46 & 46 & 46 & 46 & 46 & - & 39 \\ (10) & 39 & 39 & 39 & 39 & 39 & 39 & 39 & 39 & 39 & -\end{array}$

Note: Figures in the table represent the numbers of students considered in the analyses. The difference between each figure and the maximum. 50 , is due to lack of information as explained earlier 


\section{References and Bibliography}

11] Cooper, B.E., Statistics for Experimentalists, 1st, ed., Pergamon Press. New York, p. 293 (1969).

[2] Labani, J.M., The evaluation of the academic records of students, (Arabic text), Journal of King Saud University, Educational Sciences, 2: 17-45 (1990).

[3] Guisti, J.P., High school averages as a prediction of college success: A survey of literature, College and University, 39: 200-209 (1964).

[4] Austin, A.W., Predicting academic performance in college: Selectivity data for 2,300 American colleges, Free Press. New York (1971).

[5] Alraegi, A.H., A study of the predictive validity of twelve grade transcript data on freshman college G.P.A. for science majors, colleges of education, Saudi Arabia, Doctoral dissertation. University of Northern Colorado (1981). 
دراسـة عن الصــلة بين التحصــيل العلمي للطـلاب في مؤسسات التعليم

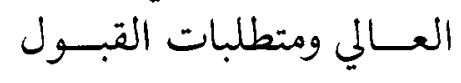

جعفر بن محمد جعفر لبني

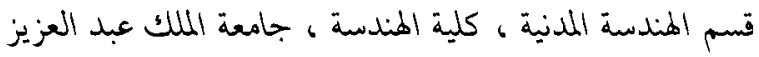

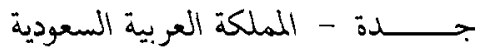

المستخلص . تهدف هذه الدراسة إلى تحديد الصلة بين متطلبات القبول في الكليات

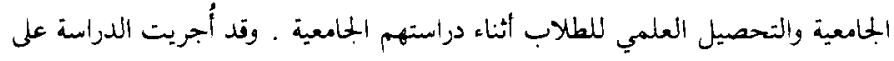

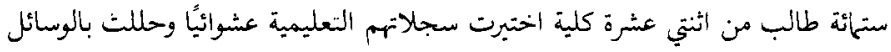

$$
\text { الإحصائية }
$$

يتبين من الدراسة أن الصلة بين مثطلبات القبول والتحصيل العلمي تكاد تكون منعدمة

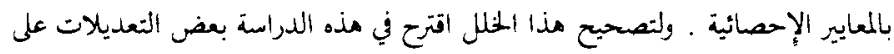

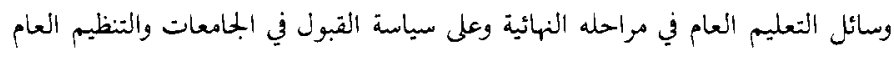

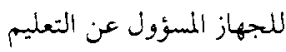

